\title{
The Retirement Consumption Puzzle: Evidences for Brazil and the State of Rio Grande do Sul
}

\section{O Enigma do Consumo na Aposentadoria: Evidências para o Brasil e o Estado Rio Grande do Sul}

\author{
Marianne Zwilling Stampe* \\ Alexandre Alves Porsse** \\ Marcelo Savino Portugal** * \\ Pedro Tonon Zuanazzi****
}

\begin{abstract}
The life cycle/permanent income theories predict that consumption would be constant over time but such result has been challenged by some empirical studies which show a systemic decrease in consumption at retirement. This paper aims to investigate the so-called retirement consumption puzzle for Brazil and the State of Rio Grande do Sul. We estimated consumption functions controlling age effects for 12 composite goods using information from the 2008-2009 Household Budget Survey. The results showed that households' expenditures systematic decrease with age for 7 composite goods (food, clothing, transport, hygiene, education, recreation and miscellaneous) and increase with age for 2 composite good (health care and housing). The patterns found to the households' expenditures by age structure brings evidence of retirement consumption puzzle in Brazil.
\end{abstract}

Keywords: Households behavior. Demographics. Retirement consumption puzzle.

Resumo: As teorias da renda permanente e do ciclo de vida predizem que o consumo é uma variável constante ao longo do tempo, porém esse resultado tem sido desafiado pelas evidencias empíricas de alguns estudos que mostram uma redução sistemática no consumo das famílias na aposentadoria. O objetivo do presente artigo é investigar o chamado enigma do consumo na aposentadoria para o caso do Brasil e do Estado do Rio Grande do Sul. Para tanto, a partir dada base de dados da Pesquisa de Orçamentos Familiares de 2008-2009, estimaram-se funções de consumo controlando efeitos de idade para 12 bens compostos. Os resultados mostram que as despesas das famílias sistemáticas se reduzem à medida que a idade aumenta para sete bens compostos (alimentação, vestuário, transporte, higiene,

\footnotetext{
* $\quad$ Doutora em Economia Aplicada pelo Programa de Pós-Graduação (PPGE) da Universidade Federal do Rio Grande do Sul (UFRGS). Professora efetiva da Universidade do Estado de Santa Catarina (Udesc). E-mail: maristampe@gmail.com

* $\quad$ Doutor em Economia pelo Programa de Pós-Graduação (PPGE) da Universidade Federal do Rio Grande do Sul (UFRGS). Professor adjunto do Departamento de Economia da Universidade Federal do Paraná (UFPR). E-mail: porsse@ufpr.br

*** Doutor em Economia pela University of Warwick. Professor titular do Departamento de Economia e Relações Internacionais (Deri) e do Programa de Pós-Graduação em Economia (PPGE) da Universidade Federal do Rio Grande do Sul (UFRGS). E-mail: msp@ufrgs.br

**** Doutorando em Economia pela Pontifícia Universidade Católica do Rio Grande do Sul (PUCRS). Pesquisador em Estatística da Fundação de Economia e Estatística do Rio Grande do Sul (FEE). E-mail: pedro@fee.tche.br
} 
educação, recreação e miscelâneas) e aumentam para dois bens compostos (saúde e residências). Utilizaram-se dados da Pesquisa de Orçamentos Familiares de 2008-2009 e estimaram-se regressões Tobit para grupos de despesas controlando para a estrutura etária. Os padrões encontrados nas despesas das famílias condicionadas pela estrutura etária mostram evidência do efeito denominado enigma do consumo na aposentadoria para o Brasil.

Palavras-chave: Comportamento das famílias. Demografia. Enigma do consumo na aposentadoria.

JEL Classification: D11; D12; J10.

\section{1 lntrodução}

The slowdown of population growth in developed countries could be characterized as a soft process evolving over the centuries due the advances in health conditions which allowed to reduce mortality and natality rates as well increase life expectancy. But this process seems to be evolving in an accelerated form in the developing countries such as Brazil. Accordingly to the United Nations data, despite Brazil have increased its participation in the world population since 1950, it is expected that population growth rate in Brazil starts to decrease after 2039 and forecasts produced by Brazilian Institute of Geography and Statistics (IBGE) indicate that Brazilian participation into the word population will decline from 2050.

Population aging is a consequence of low fertility and mortality rates and high life expectancy. Thus, there is a reduction in the proportion of children in the population and a consequent increase in the proportion of people in older age groups. In Brazil, the State of Rio Grande do Sul (RS) presents the highest percentage of aged individuals and the lowest percentage of children into total population, thus being the region in which the process of demographic change is more pronounced. The Foundation of Economics and Statistics of Rio Grande do Sul predicts that population growth rate in RS will became negative from 2030, very early compared to the Brazil as a whole. However, it is worth noting that Brazil and Rio Grande do Sul are still at the stage where the economically active population (EAP) is the most representative among the age groups.

There are several channels by which demographics affects economic system. Miles (1999) mentions that savings rate tends to decrease in an economy where young people or people over 65 years predominate population. The negative impact of demographic change on the savings rate is a result consistent with the life cycle hypothesis (MODIGLIANI, 1970). However, lower savings would lead to less private investments affecting capital formation as well economic growth (AZARIADIS, 2006; MILES, 1999; ALVES, 2008). 
Considering demographic change in Brazil, Wong and Carvalho (2006) discuss the effect on labor supply and economic productivity and government expenditures. Brazilian economically active population (EAP) is expected to grow at least until 2045 and after this point tends to decrease. Thus demographic bonus have a short time window in Brazil which will be close few decades ahead and expansion of economic growth will became dependent of improvements in labor productivity. In addition, population aging demands more health and social security resources, resulting in an increase in government spending (WONG; CARVALHO, 2006). Turra's (2001) estimations of the revenue to expenditure ratio for Brazil show a considerable decline for the period 2000 to 2050, allowing to forecast that demographic change will represent systematic pressure on government's fiscal deficit compromising public investments.

Besides government spending, another important issue associated with population aging is that the structure of household consumption may change. As the aged population increases, there must be a change in the structure of household consumption. Analyzing household consumption behavior, Lefèbvre (2006) show that some groups of goods tends to be more favored in an ageing society (housing, health, leisure, etc.) while other tends to be less favored (food, clothing, transportation, etc.). The effect of demographic change on household consumption is another important channel affecting economic system and some studies have found a retirement consumption puzzle, evidencing that household consumption tends to decrease at the retirement (HAMERMESH, 1984; FAIR; DOMINGUEZ, 1991; BANKS; BLUNDELL; TANNER, 1998; BERNHEIM; SKINNER; WEINBERG, 2001; HURD; ROHWEDDER, 2003; SCHWERDT, 2005; HAIDER; STEPHENS JR., 2007; BATTISTIN et al., 2009; LI; CHI; WU, 2015). This result challenges the implications of the life cycle/permanent income hypothesis by which rational households should be saving adequately for retirement and their consumption would be expected to not reduce.

This paper aims to investigate the household consumption behavior over the life cycle in Brazil and the State of Rio Grande do Sul searching for evidences about the retirement consumption puzzle. To the best of our knowledge, this paper is the first to study this issue for Brazil and the accelerated demographic change process experienced by Brazilian economy put in evidence the need to explore such issue. Additionally, the analysis is also applied to the households living in the State of Rio Grande do Sul (RS) because this is the region where population ageing is growing very quickly if compared to the resting of Brazil. The information about household expenditures is obtained from the 2008/2009 Household Budget Survey and the empirical approach consists in using Tobit regression for estimating consumption function controlling for age effects based on Lefèbvre (2006) and Farinha (2008). We found evidence of the retirement consumption puzzle for Brazil and RS for 
the composite goods food, clothing, transport, hygiene, education, recreation and miscellaneous.

The paper is organized as follows. Section 2 presents a brief literature review relating consumption behavior with the so-called retirement consumption puzzle. Section 3 explores some data about the age structure and consumption expenditures in Brazil and the State of Rio Grande do Sul. Section 4 presents the methodological approach used in the empirical analysis. Section 5 report and discuss the results and section 6 concludes.

\section{Literature Review}

The first consumption theory formulated into the field of economic science came from Keynes which defined consumption as a direct function of disposable income and introduced the concept of marginal propensity to consume. Keynes (1982) also argues that there are subjective factors that lead individuals to stop spending their income as a precautionary measure, security, time value of money (interest), among others.

The consumption theory founded by the Keynesian approach continued being improved into the economic science and gave rise to the life cycle theory, developed by Franco Modigliani, Richard Brumberg and Albert Ando in the 1950s. This theory postulates that consumption is constant over time, and that individuals save while they receive labor income to spend it during retirement, when they no longer receive income from work. Thus, periods of higher income represent savings and periods of lower income or of no income at all represent dissaving, allowing consumption to be constant throughout life. The main difference between life cycle theory and the Keynesian consumption theory is that the latter considers only the current income and the former considers the lifelong income (MORAES; FAMÁ; KAYO, 1998).

The permanent income theory of consumption was developed by Milton Friedman in 1957. Accordingly to this theory, the permanent income determines consumption, i.e., the share of current income individuals believe to be persistent over time. Thus, the permanent income can be defined as the average between present income and income from the previous period (DORNBUSCH; FISCHER, 1982). Just as the life cycle theory, this theory seeks to show that the marginal propensity to consume in the short and long run is different. Thus, the life cycle and permanent income theories can be treated as complementary since the former emphasizes the motivation to save and the latter shows how individuals calculate their expected future income (MORAES; FAMÁ; KAYO, 1998).

A common feature in the life cycle/permanent income theories (LCPIT) is that households have rational expectations, implying that they can properly fore- 
cast their permanent income considering their cycle of life. In this case household consumption should be constant over time and not change at retirement (HAIDER; STEPHENS JR., 2007). However, several studies have founded evidences which challenges the implications of LCPIT showing that consumption tends to decrease at retirement (HAMERMESH, 1984; FAIR; DOMINGUEZ, 1991; BANKS; BLUNDELL; TANNER, 1998; BERNHEIM; SKINNER; WEINBERG, 2001; HURD; ROHWEDDER, 2003; SCHWERDT, 2005; HAIDER; STEPHENS JR., 2007; BATTISTIN et al., 2009; LI; CHI; WU, 2015).

Accordingly to Lefèbvre (2006) those studies address the issue of consumption at older ages concluding that consumption is expressively reduced at retirement, resulting in the so-called "retirement-consumption puzzle". The explanation for this phenomenon would be that the marginal utility of consumption, and not consumption itself, would be smoothed over time, so that changes in family size, number of workers (economically active individuals), mortality or population aging may adjust the marginal utility consumption and cause consumption to fall at advanced ages. Furthermore, the reduction in consumption could also be explained by limitations in households' knowledge to forecast their correct permanent income and by the substitution effect between consumption and leisure which tends to increase over the time (HURD; ROHWEDDER, 2003; SMITH, 2004).

As showed by Hamermesh (1984), change in spending of elderly people indicates a drop in consumption and that their income is not enough to support their consumption, indicating that their private and public savings are insufficient to sustain consumption over time. The author argues that uncertainty on survival influences the increase or decrease of consumption by age, as it produces two opposite effects: the increase in consumption is related to take advantage of what you can ' $t$ be here to enjoy or a fall in consumption is associated with a long horizon of life.

In spite of retirement-consumption puzzle be evidenced for many countries accordingly to the literature, to the best of our knowledge this issue was not yet investigated for the Brazilian economy. Concerning the effects of demographic change and ageing in Brazil, some studies have discussed mainly implications on labor market and governments expenditures (WONG; CARVALHO, 2006; TURRA, 2001) while other discuss the impact on economic growth (ALVES, 2004, 2008; AZZONI; MENEZES-FILHO; MENEZES, 2005; MENEZES; SILVEIRA-NETO; AZZONI, 2011). Accordingly to data from 2010 Brazilian Demographic Census, the retired population with age over than 50 years old accounts for $50.3 \%$ of the total population in that age group. ${ }^{1}$ As people tends to retire very early and demographic change evolves very quickly in Brazil, the investigation about evidences related to the retirement-consumption puzzle proposed in this study is very relevant.

1 In the State of Rio Grande do Sul the same indicator accounts for $57.7 \%$. 


\section{Data}

The analysis carried out in this study uses information obtained from the 2008-2009 Household Budget Survey (POF) published by the IBGE. POF is a sampling survey and provides detailed information about household expenditure encompassing aspects related with consumption habits, expenditure allocation and income distribution as well other characteristics of households. Its database represents 190.1 million of households for Brazil and 6,7 million for Rio Grande do Sul. This section explores some data from this survey to trace a picture about the characteristics of households and their expenditure in Brazil and Rio Grande do Sul.

Table 1 presents the percentage composition of households considering the number of residents by age groups. The first column indicate that there is "no resident" into the household on that age group and the other two columns similarly accounts for "one resident" and "two residents or more". The incidence of households with two or more elderly people in Rio Grande do Sul (6.2\%) is higher than in Brazil (5.2\%), but the opposite occurs we consider young people into the first age groups ( 0 to 14 years old). This result show that demographic transition towards an ageing society is more accelerated in the State of Rio Grande do Sul if compared to the entire country. In fact, the incidence of households with two or more residents in Rio Grande do Sul is higher than Brazil in all age groups from 45 years old.

Tables 2 and 3 reports data about per capita expenditure for 12 composite goods by age groups for Brazil (BR) and Rio Grande do Sul (RS), respectively. The main composite goods into the households' budget are housing (35.0\% for $\mathrm{BR}$ and $33.5 \%$ for RS), food (18.6\% for BR and $18.7 \%$ for RS) and transport (18.2\% for BR and $18.5 \%$ for RS). Together, the participation of these composite goods in the total household budget accounts for $72.6 \%$ for Brazil and 70.7\% for Rio Grande do Sul. However, those shares have significant differences among households if age composition is accounted for.

Considering households containing young people (0 to 24 years old), the participation for expenditures on food and transport goods tend to overcome the average both in Brazil and Rio Grande do Sul while for expenditure for housing goods tend be lower than the average. Considering households containing mostly old people ( 65 years old and over) the opposite occurs for food and transport goods as well for also transport goods, since the budget share for the first two goods is higher than average and for the third is lower. Compared to the average, such shares seem to behave slightly different in the households formed by people aged from 55 to 64 years old.

Other composite goods are less representative into the household budget but seem to be more sensitive to ageing. For instance, for Brazil the education share for type households 0-9 years old decreases from 3.0\% in Brazil (3.8\% for RS) to $0.9 \%$ 
( $0.8 \%$ in RS) for type households 65 or more years old. As expected, the health care share for type households 0-9 years old increases from $5.4 \%$ in Brazil (5.2\% in RS) to $12.5 \%$ (12.0\% in RS) for type households 65 or more years old.

The picture observed by that information from the household expenditures database allow to identify relevant changes in the consumption behavior over the life cycle in Brazil and Rio Grande do Sul. The extent to which that changes characterize the so-called retirement consumption puzzle will be evaluated using appropriated econometric tools which are described in the sext section.

Table 1 - Composition of households by number of residents in age groups, Rio Grande do Sul and Brazil

\begin{tabular}{|c|c|c|c|c|c|c|}
\hline \multirow[b]{2}{*}{ Age Group } & \multicolumn{3}{|c|}{ RIO GRANDE DO SUL } & \multicolumn{3}{|c|}{ BRASIL } \\
\hline & No resident & 1 resident & $\begin{array}{c}2 \text { residents or } \\
\text { more }\end{array}$ & No resident & 1 resident & $\begin{array}{c}2 \text { residents or } \\
\text { more }\end{array}$ \\
\hline 0 to 9 years & $68,9 \%$ & $21,6 \%$ & $9,5 \%$ & $64,5 \%$ & $23,3 \%$ & $12,2 \%$ \\
\hline 10 to 14 years & $78,2 \%$ & $17,9 \%$ & $3,9 \%$ & $76,1 \%$ & $18,3 \%$ & $5,6 \%$ \\
\hline $15 \mathrm{t}$ to 24 years & $65,2 \%$ & $24,3 \%$ & $10,5 \%$ & $60,4 \%$ & $25,4 \%$ & $14,2 \%$ \\
\hline 25 to 34 years & $66,6 \%$ & $22,9 \%$ & $10,5 \%$ & $60,3 \%$ & $26,9 \%$ & $12,8 \%$ \\
\hline 35 to 44 years & $65,1 \%$ & $24,6 \%$ & $10,2 \%$ & $63,9 \%$ & $25,8 \%$ & $10,3 \%$ \\
\hline 45 to 54 years & $68,9 \%$ & $22,0 \%$ & $9,1 \%$ & $69,5 \%$ & $22,6 \%$ & $7,9 \%$ \\
\hline 55 to 64 years & $77,6 \%$ & $16,5 \%$ & $5,9 \%$ & $79,0 \%$ & $16,1 \%$ & $4,9 \%$ \\
\hline 65 or more years & $78,0 \%$ & $15,8 \%$ & $6,2 \%$ & $80,0 \%$ & $14,8 \%$ & $5,2 \%$ \\
\hline
\end{tabular}

Source: Elaborated by the authors by POF 2008-2009 microdata IBGE (2010).

Note: The percentage composition was calculated using the sample weights to expand the data for the whole population. 
Table 2 - Composition of household per capita expenditure, Brazil

\begin{tabular}{|c|c|c|c|c|c|c|c|c|c|}
\hline & $\begin{array}{c}\text { All } \\
\text { Brazi- } \\
\text { lians }\end{array}$ & $\begin{array}{c}0 \text { to } \\
9 \\
\text { years }\end{array}$ & $\begin{array}{c}10 \text { to } \\
14 \\
\text { years }\end{array}$ & $\begin{array}{c}15 \text { to } \\
24 \\
\text { years }\end{array}$ & $\begin{array}{c}25 \text { to } \\
34 \\
\text { years }\end{array}$ & $\begin{array}{c}35 \text { to } \\
44 \\
\text { years }\end{array}$ & $\begin{array}{c}45 \text { to } \\
54 \\
\text { years }\end{array}$ & $\begin{array}{c}55 \text { to } \\
64 \\
\text { years }\end{array}$ & $\begin{array}{l}65 \text { or } \\
\text { more } \\
\text { years }\end{array}$ \\
\hline Food & $18,6 \%$ & $21,4 \%$ & $21,5 \%$ & $19,8 \%$ & $19,2 \%$ & $18,5 \%$ & $17,4 \%$ & $17,2 \%$ & $16,9 \%$ \\
\hline $\begin{array}{l}\text { Health } \\
\text { Care }\end{array}$ & $7,5 \%$ & $5,4 \%$ & $5,3 \%$ & $5,6 \%$ & $5,5 \%$ & $5,7 \%$ & $7,1 \%$ & $8,9 \%$ & $12,5 \%$ \\
\hline $\begin{array}{l}\text { Miscella- } \\
\text { neous Ex- } \\
\text { penses }\end{array}$ & $2,7 \%$ & $2,5 \%$ & $2,4 \%$ & $2,9 \%$ & $3,0 \%$ & $2,7 \%$ & $2,8 \%$ & $3,1 \%$ & $2,3 \%$ \\
\hline Education & $2,6 \%$ & $3,0 \%$ & $3,9 \%$ & $3,8 \%$ & $2,8 \%$ & $3,2 \%$ & $3,2 \%$ & $1,9 \%$ & $0,9 \%$ \\
\hline Smoking & $0,5 \%$ & $0,5 \%$ & $0,5 \%$ & $0,5 \%$ & $0,5 \%$ & $0,5 \%$ & $0,6 \%$ & $0,5 \%$ & $0,4 \%$ \\
\hline Housing & $35,0 \%$ & $33,2 \%$ & $33,0 \%$ & $32,1 \%$ & $31,9 \%$ & $34,3 \%$ & $33,6 \%$ & $35,4 \%$ & $42,5 \%$ \\
\hline Hygiene & $2,2 \%$ & $2,6 \%$ & $2,5 \%$ & $2,7 \%$ & $2,5 \%$ & $2,3 \%$ & $2,1 \%$ & $1,8 \%$ & $1,6 \%$ \\
\hline $\begin{array}{c}\text { Other Ex- } \\
\text { penses }\end{array}$ & $4,8 \%$ & $3,5 \%$ & $3,7 \%$ & $3,8 \%$ & $4,3 \%$ & $4,7 \%$ & $5,4 \%$ & $6,1 \%$ & $5,5 \%$ \\
\hline Recreation & $1,9 \%$ & $2,1 \%$ & $1,9 \%$ & $2,2 \%$ & $2,2 \%$ & $2,2 \%$ & $1,9 \%$ & $1,6 \%$ & $1,2 \%$ \\
\hline $\begin{array}{l}\text { Personal } \\
\text { Services }\end{array}$ & $1,0 \%$ & $1,0 \%$ & $1,0 \%$ & $1,1 \%$ & $1,1 \%$ & $1,1 \%$ & $1,1 \%$ & $1,0 \%$ & $0,9 \%$ \\
\hline Transport & $18,2 \%$ & $18,8 \%$ & $18,3 \%$ & $19,1 \%$ & $21,3 \%$ & $19,5 \%$ & $19,6 \%$ & $18,6 \%$ & $11,8 \%$ \\
\hline Clothing & $5,0 \%$ & $6,0 \%$ & $6,0 \%$ & $6,3 \%$ & $5,8 \%$ & $5,4 \%$ & $5,1 \%$ & $3,9 \%$ & $3,5 \%$ \\
\hline
\end{tabular}

Source: Calculated by the author based on microdata from 2008-2009 POF (IBGE, 2010). 
Table 3 - Composition of household per capita expenditure, Rio Grande do Sul

\begin{tabular}{|c|c|c|c|c|c|c|c|c|c|}
\hline & $\begin{array}{c}\text { All } \\
\text { Gaú- } \\
\text { chos }\end{array}$ & $\begin{array}{l}0 \text { to } 9 \\
\text { years }\end{array}$ & $\begin{array}{c}10 \text { to } \\
14 \\
\text { years }\end{array}$ & $\begin{array}{c}15 \text { to } \\
24 \\
\text { years }\end{array}$ & $\begin{array}{c}25 \text { to } \\
34 \\
\text { years }\end{array}$ & $\begin{array}{c}35 \text { to } \\
44 \\
\text { years }\end{array}$ & $\begin{array}{c}45 \text { to } \\
54 \\
\text { years }\end{array}$ & $\begin{array}{c}55 \text { to } \\
64 \\
\text { years }\end{array}$ & $\begin{array}{l}65 \text { or } \\
\text { more } \\
\text { years }\end{array}$ \\
\hline Food & $18,7 \%$ & $20,4 \%$ & $21,4 \%$ & $19,6 \%$ & $18,7 \%$ & $18,4 \%$ & $19,2 \%$ & $17,4 \%$ & $17,2 \%$ \\
\hline $\begin{array}{c}\text { Health } \\
\text { Care }\end{array}$ & $7,3 \%$ & $5,2 \%$ & $5,6 \%$ & $5,7 \%$ & $5,0 \%$ & $5,7 \%$ & $7,4 \%$ & $8,6 \%$ & $12,0 \%$ \\
\hline $\begin{array}{c}\text { Miscella- } \\
\text { neous }\end{array}$ & $3,4 \%$ & $3,8 \%$ & $3,0 \%$ & $3,9 \%$ & $3,7 \%$ & $3,4 \%$ & $4,2 \%$ & $3,2 \%$ & $2,6 \%$ \\
\hline Expenses & & & & & & & & & \\
\hline Education & $2,4 \%$ & $2,4 \%$ & $3,4 \%$ & $4,0 \%$ & $2,8 \%$ & $2,6 \%$ & $2,9 \%$ & $1,6 \%$ & $0,8 \%$ \\
\hline Smoking & $0,7 \%$ & $0,8 \%$ & $1,0 \%$ & $0,8 \%$ & $0,6 \%$ & $0,7 \%$ & $0,8 \%$ & $0,6 \%$ & $0,4 \%$ \\
\hline Housing & $33,5 \%$ & $32,9 \%$ & $32,5 \%$ & $30,8 \%$ & $30,3 \%$ & $32,6 \%$ & $33,4 \%$ & $34,3 \%$ & $38,8 \%$ \\
\hline Hygiene & $2,0 \%$ & $2,4 \%$ & $2,4 \%$ & $2,3 \%$ & $2,4 \%$ & $2,2 \%$ & $2,1 \%$ & $1,7 \%$ & $1,4 \%$ \\
\hline $\begin{array}{c}\text { Other } \\
\text { Expenses }\end{array}$ & $5,0 \%$ & $4,0 \%$ & $3,8 \%$ & $4,3 \%$ & $4,1 \%$ & $5,1 \%$ & $5,5 \%$ & $5,8 \%$ & $6,3 \%$ \\
\hline $\begin{array}{c}\text { Recrea- } \\
\text { tion }\end{array}$ & $2,0 \%$ & $2,1 \%$ & $2,6 \%$ & $2,4 \%$ & $2,4 \%$ & $2,8 \%$ & $1,6 \%$ & $1,6 \%$ & $1,4 \%$ \\
\hline $\begin{array}{l}\text { Personal } \\
\text { Services }\end{array}$ & $0,8 \%$ & $0,7 \%$ & $0,8 \%$ & $0,9 \%$ & $0,9 \%$ & $0,9 \%$ & $0,9 \%$ & $0,8 \%$ & $0,8 \%$ \\
\hline Transport & $18,5 \%$ & $18,9 \%$ & $17,1 \%$ & $18,7 \%$ & $22,6 \%$ & $19,8 \%$ & $16,6 \%$ & $19,9 \%$ & $14,7 \%$ \\
\hline Clothing & $5,5 \%$ & $6,4 \%$ & $6,6 \%$ & $6,7 \%$ & $6,5 \%$ & $5,9 \%$ & $5,3 \%$ & $4,5 \%$ & $3,7 \%$ \\
\hline
\end{tabular}

Source: Calculated by the author based on microdata from 2008-2009 POF (IBGE, 2010).

\section{Methodology}

This section first describes some aspects related to the treatment of the database which were necessary to be done to allow carry out the empirical analysis. Following this description, the methodological tools used for estimating the consumption function are presented.

In order to analyze the consumption behavior for different composite goods by age group, the data on household and individuals were cross-matched based on the number of household, sequence, and check digit, common in both databases. $^{2}$ The sequence variable into POF provides a sequential number for each of the

$2 \quad$ Accordingly to the IBGE (2004b), a household is a house structured separately (limited by walls or fences and covered by a roof) with independent access and made up of one or more rooms. For IBGE, according to the same publication cited in the previous paragraph, the term "household" is 
survey sector ${ }^{3}$ included in the sample, while the check digit variable identifies the sequential number assigned to the respective survey sector. As there can be more than one person in the household, the consumer unit variable allows to identify a resident or group of residents who share the same power supply or share the living expenses.

The amount of households' resident variable allowed opening the household database and entering the age of all residents through the creation of new variables such as number of economically active persons, number of children, number of elderly. Thus, if the household has four residents, it has four lines in the corresponding People database containing information about the age of each resident. Additionally, we create variables for economically active people to analyze which age groups under this category contribute more remarkably to consumption. Data such as sex, education, income, among others, were also included.

The 2008-2009 POF investigates the families' expenditure with different types of consumer goods, as well as the socioeconomic characteristics of households (income, education, etc.) and personal attributes of residents (e.g., sex, age and access to credit). Expenses have a record of 13,784 items, containing information on the amount of money spent on each good (annualized or deflated), on how the good was purchased (cash payment, installment payment, exchange, own production), and other relevant information. Using codes for economic activity, we grouped the expenditure database into 12 composite goods: food, housing, clothing, transport, hygiene, health care, education, recreation, smoking, personal services, miscellaneous expenses and other expenses.

The methodological approach applied here consists in estimating consumption functions for each composite good controlling for age. The estimation model and method used in this analysis follow Lefèbvre (2006) and Farinha (2008). Equation 1 represents the consumption function specified for each composite good:

$$
C_{i}^{*}=\beta_{0}+\beta_{1} \ln Y_{i}+\sum_{k=2}^{18} \beta_{k} X_{i, l}+u_{i}
$$

represented by the consumer unit and meets international recommendations, denoting "people linked by kinship ties, dependence or domestic standards of living, without explicit reference to consumption or expenditure" (IBGE, 2004b, p. 10). There are cases in which households had more than one consumer unit, and, in these cases, the demographic data (number of children, elderly and working-age people by age group) of each consumer unit were used for the demographic structure of the household. This simplification was necessary because the adjustment would otherwise be too time-consuming, as combining the household and people databases was not an easy task.

The survey sector corresponds to the geographical basis sectors of the 2000 Demographic Census. 
where $C_{i}^{*}$ represents the expenditure share of the composite good into the total household expenditure by household $i^{4}$ and $\ln Y_{i}$ represents the logarithm of per capita income of the consumer unit (family) and $X_{i, l}$ represents a vector of socioeconomic characteristics, group of ages and locational variables. The variable representing income corresponds to the sum of the gross monetary income of all residents in the consumer unit, obtained from work, transfers, other types of income and from the positive balance of financial transactions, plus non-monetary income. Importantly, some studies use some measure related to wealth rather than the current income to estimate the consumption function (FARINHA, 2008), but this variable is not available for Brazil. Thus we choose to use the per capita income of the consumer unit from the POF to estimate the model.

The use of dependent variable in terms of percentage share in the total income is useful to deal with endogeneity problem. The income variable, regarded as an explanatory variable of consumption, can also be explained by the consumption, since the higher the income, the lower the consumption, characterizing a form of endogeneity or reverse causality (FARINHA, 2008; CAMERON; TRIVEDI, 2009; WOOLDRIDGE, 2008). Thus, using percent of consumption avoid the simultaneous effect of consumption on income, as the percentage of consumption doesn 't affect income.

Table 4 presents the description of all variables into the vector $X_{i, l}$. The variable $H S_{i}$ represents a dummy variable which gives the value of 1 if the household have high school or 0 otherwise, and the variable $U G_{i}$ is also a dummy variable for undergraduate education. The other variables are the demographic variables, which were obtained from the combination of the household and people databases. We separate the individuals by age in the following groups: Age0-9, Age10-14, Age15-24, Age25-34, Age35-44, Age45-54, Age55-64, Age65+. The numbers after the name "Age" reflect the ages considered in each group, and we computed the number of family members in each age group. The variable MALES is a dummy variable giving the value of 1 if the individual is male or 0 otherwise. URBAN is also a dummy variable indicating if the individual lives in a urban area and the variables $\mathrm{R} 1$ to $\mathrm{R} 4$ represents dummy variables for the following regions, respectively: $\mathrm{Mi}-$ dwest, Southeast, North and South. The based-category is the Northeast.

Compared to Lefèbvre (2006), the present study represents an improvement in terms of database. That study included only data on household heads whereas we included demographic data on household members. Additionally, as we are dealing with data from a complex sample, it is appropriate to include the various features of the sampling plans into the estimation procedures. The statistical sof-

$4 \quad$ The variable represents only positive values and thus our dependent variable is latent. Consumer spending data were those recorded on the book of expenses, expenses incurred within a 90-day period, expenses incurred within a 12-month period, individual expenses, other expenses, expenditures with domestic services and expenditures with vehicles. 
tware Stata allows to deal with complex samples through the suy command (STATA, 2013), providing a form to control for conglomerate variable (sample weight and stratum ${ }^{5}$ ) and to produce accurate estimates (SILVA; PESSOA; LILA, 2002; BATTISTI, 2008).

Besides the stratum, the suy command needs to determine the sample weight and the conglomerate variable. The expansion of the sample takes into account the sample weight, in which each household belonging to the Household Budget Survey sample is a certain number of permanent households of the population (universe) from which this sample was selected. Hence, for each household in the sample is assigned a sample weight or expansion factor that, when attributed to the characteristics investigated by the POF, allows obtaining estimates of the quantities of interest. This conglomerate variable is usually defined as the primary sample unit (PSU) and each conglomerate, formed by $N_{i}$ secondary sample units. As only the secondary sample units were available, and as we combined the household and people databases, taking the household as reference and as the household and the selection of sectors is made proportionally to the number of households, we considered them as the conglomerate variable.

Table 4 - Description of the variables

\begin{tabular}{|c|c|}
\hline Variable & Description \\
\hline $\mathrm{C}_{\mathrm{i}}^{*}$ & Positive share of composite good in the total income \\
\hline $\ln Y$ & Natural logarithmic for income \\
\hline HS & Dummy for high school \\
\hline UG & Dummy for undergraduate program \\
\hline MALE & Dummy for Male \\
\hline URBAN & Dummy for Urban \\
\hline AGE0-9 & Number of family members in age of 0 to 9 years old \\
\hline AGE10-14 & Number of family members in age of 10 to 14 years old \\
\hline AGE15-24 & Number of family members in age of 15 to 24 years old \\
\hline AGE25-34 & Number of family members in age of 25 to 34 years old \\
\hline AGE35-44 & Number of family members in age of 35 to 44 years old \\
\hline AGE45-54 & Number of family members in age of 45 to 54 years old \\
\hline
\end{tabular}

to be continued...

$5 \quad$ Stratum represent populations divided into mutually exclusive subsets, which are then estimated by combining the samples obtained from each stratum. In the POF, a conglomerate plan was adopted, with geographical and statistical stratification (from the variable that characterizes the socioeconomic strata) of the primary sample units (PSUs), which correspond to the sectors in the 2000 Demographic Census. The sectors were selected by systematic sampling, in which probability was proportional to the numbers of households in each sector. In relation to the sample design, the allocation of the sectors selected in each stratum was proportional to the total number of permanent private households in the stratum, conditional on the existence of at least two sample sectors in each stratum. 
conclusion.

\begin{tabular}{cc}
\hline Variable & Description \\
\hline AGE55-64 & Number of family members in age of 55 to 64 years old \\
AGE65+ & Number of family members in age of 65 or more \\
R1 & Dummy for Midwest Region \\
R2 & Dummy for Southwest Region \\
R3 & Dummy for North Region \\
R4 & Dummy for South Region \\
\hline
\end{tabular}

Source: Elaborated by the authors.

Although some studies use only the expansion factor to evaluate the whole population, which considers a simple random sample, Vieira (2001) and Battisti (2008) suggest that the adoption of a simple random sample instead of a complex one can be inefficient when the population is not homogeneous and when subgroups differ in size. The adoption of a complex sample procedure also is important to estimate the variance of standard errors, allowing us to determine the accuracy of the estimates.

Normally, the estimators are linearly weighted, as in the case of suy command, but our empirical strategy for estimating the consumption function uses the Tobit model and the maximum likelihood method. This strategy was adopted because we have a non-negligible fraction of the sample with zero value for the dependent variable $(y)$ while other values of $y$ are positive and continuously distributed. In this way, we can define $y$ as the maximum value between 0 and the latent variable $y^{*}$, which represent the positive values for $y$ (WOOLDRIDGE, 2008):

$$
y=\max \left(0, y^{*}\right)
$$

The estimated model shown in equation 1 uses the latent variable $y^{*}$ as dependent variable. It is assumed that the latent variable is normally distributed and homoscedastic. It is important to note that the coefficients estimated by the model defined in equation 1 will measure the partial effects of the explanatory variables $(x)$ on the expected value of the $y^{*}$ variable, that is, $E\left(y^{\prime \prime} \mid x\right)$. As the variable to be explained is $y$, we need to estimate the expected value of $y$ as a function of $x$, that is, $E(y \mid x)$. Following Wooldridge (2008), $E(y \mid x)$ is obtained by:

$$
E(y \mid x)=P(y>0 \mid x) \cdot E(y \mid y>0, x)=\Phi(x \beta / \sigma) \cdot E(y \mid y>0, x)
$$

Representing the inverse of Mills ratio by $\lambda$, we have $\mathrm{E}(\mathrm{y} \mid \mathrm{y}>0, x)=x \beta+\sigma \lambda(x \beta / \sigma)$, where $\lambda(\mathrm{c})=\varnothing / \Phi, \varnothing$ is the standard normal probability density function and $\Phi$ is 
the standard cumulative density function. From this definition for $\mathrm{E}(\mathrm{y} \mid \mathrm{y}>0, x)$ we have:

$$
E(y \mid x)=\Phi\left(\frac{x \beta}{\sigma}\right)\left[x \beta+\sigma \lambda\left(\frac{x \beta}{\sigma}\right)\right]=\Phi\left(\frac{x \beta}{\sigma}\right) x \beta+\sigma \varnothing\left(\frac{x \beta}{\sigma}\right)
$$

Thus, in the Tobit model, $\mathrm{E}(y \mid x)$ will be a non-linear function of $x$ and $\beta$, and $\mathrm{E}(y \mid x)$ always give a positive value. The partial effects of $\mathrm{x}$ on $\mathrm{E}(y \mid y>0, x)$ and on $\mathrm{E}(y \mid x)$ have the same sign as the $\beta$ coefficient, but the magnitude of the effect depends on all the values of the explanatory variables and parameters.

The partial derivative of $\mathrm{E}(y \mid x)$ with respect to $\mathrm{x}$ is given by:

$$
\frac{\partial E(y \mid x)}{\partial x}=\frac{\partial P(y>0, x)}{\partial x_{j}} \cdot E(y \mid y>0, x)+P(y>0 \mid x) \cdot \frac{\partial E(y \mid y>0, x)}{\partial x_{j}}
$$

As $P(y>0 \mid x)=\Phi\left(\frac{x \beta}{\sigma}\right)$ equation 5 can be simplified and rewritten as follow:

$$
\frac{\partial E(y \mid x)}{\partial x}=\beta_{j} \Phi\left(\frac{x \beta}{\sigma}\right)
$$

It is worth noting that the $\beta_{\mathrm{j}}$ estimated coefficients must be multiplied by an adjustment factor to be comparable with the estimated value of $\mathrm{y}\left(\widehat{y_{j}}\right)$. As $0<\Phi\left(\frac{x \beta}{\sigma}\right)<1$, the Tobit coefficients are lower than Ordinary Least Square coefficients, but have the same sign as the original Ordinary Least Square estimation. Thus this method was applied for estimating the consumption function in this study since it improves the accuracy of the estimates considering that the database is characterized as a complex sample.

\section{Results}

The results for the consumption functions estimated for each composite good are reported in Tables 5 and 6, respectively for Brazil and Rio Grande do Sul. These results allow us to capture how household expenditure behavior is affected by per capita income, age, education, sex and locational factors such as urban and regional areas. The estimations were obtained using the Tobit procedure and the suy command for the complex sample as explained in the previous section. As we are dealing with cross-sectional data, the estimations also correct for heteroscedasticity. The $\mathrm{F}$ test rejected the null hypothesis that all coefficients are statistically equal to zero for all composite goods equations estimated. 


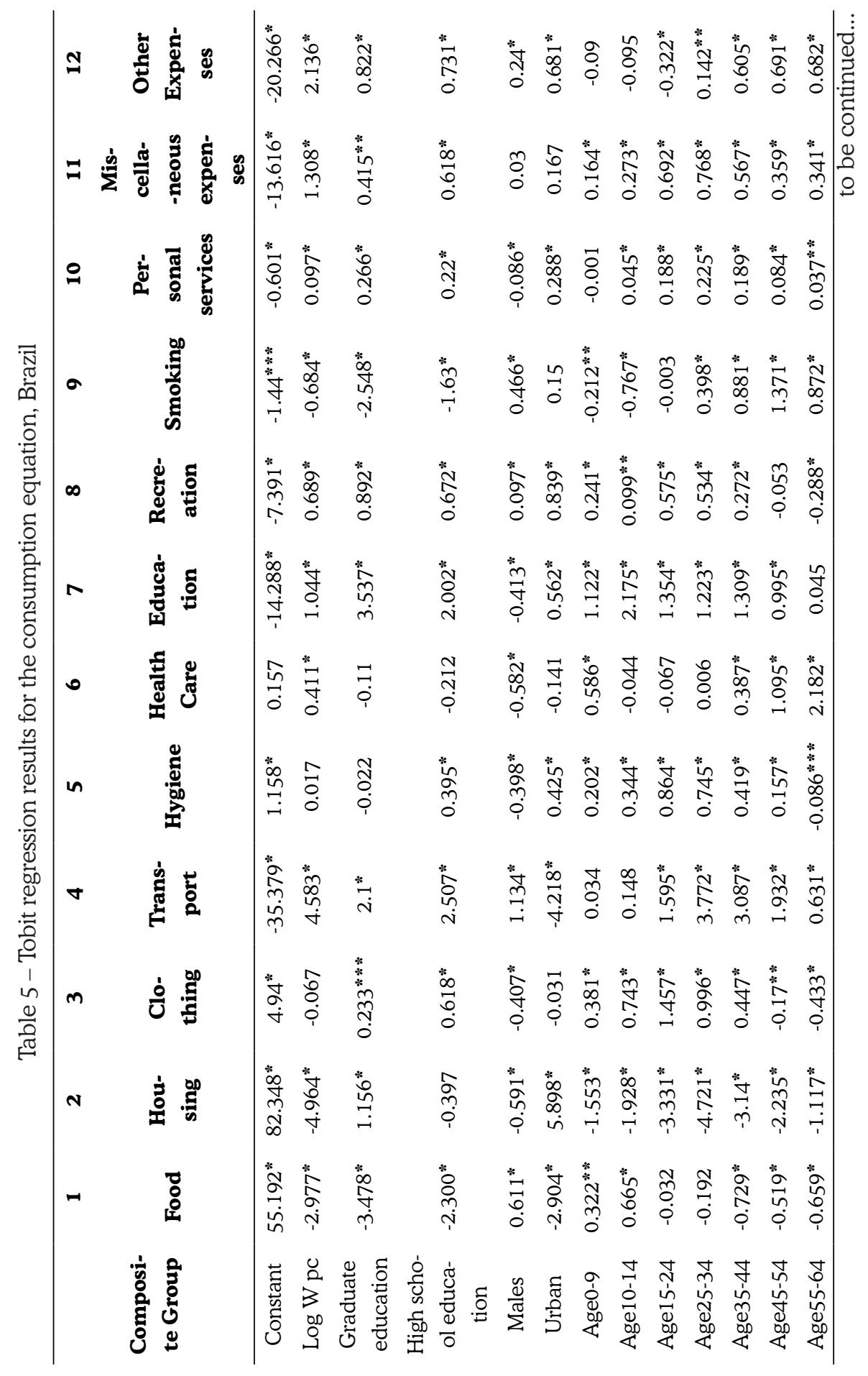




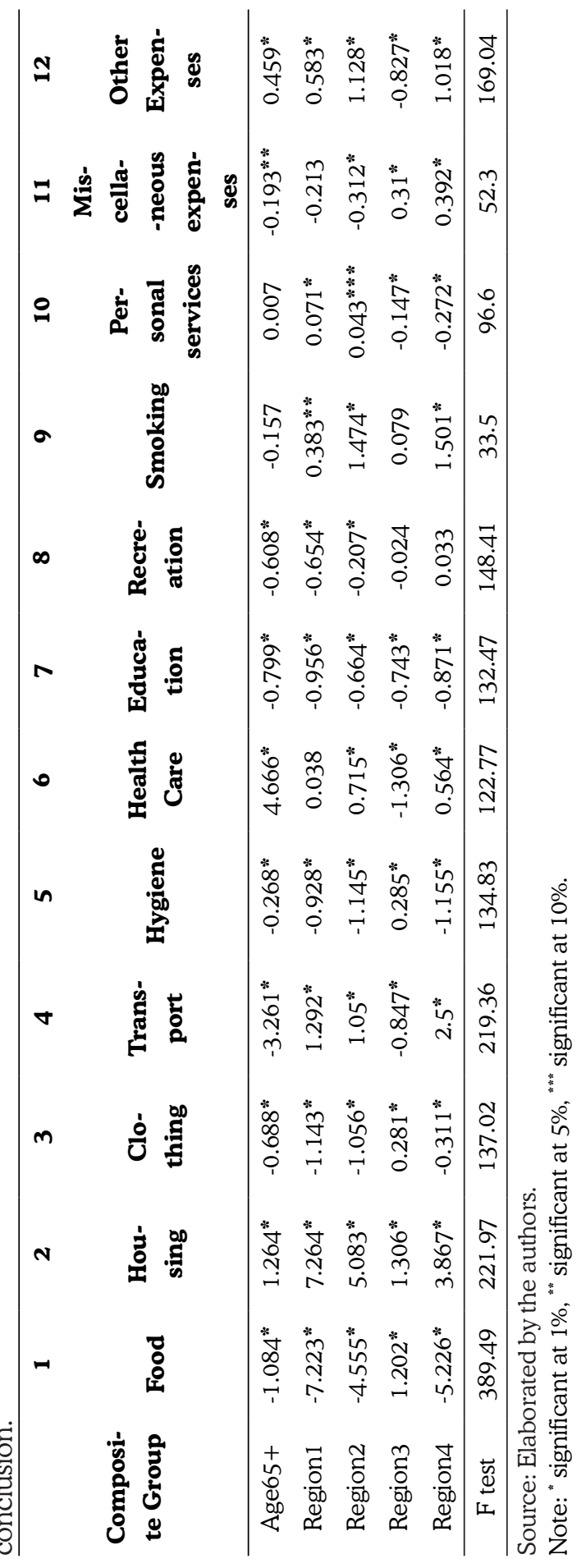




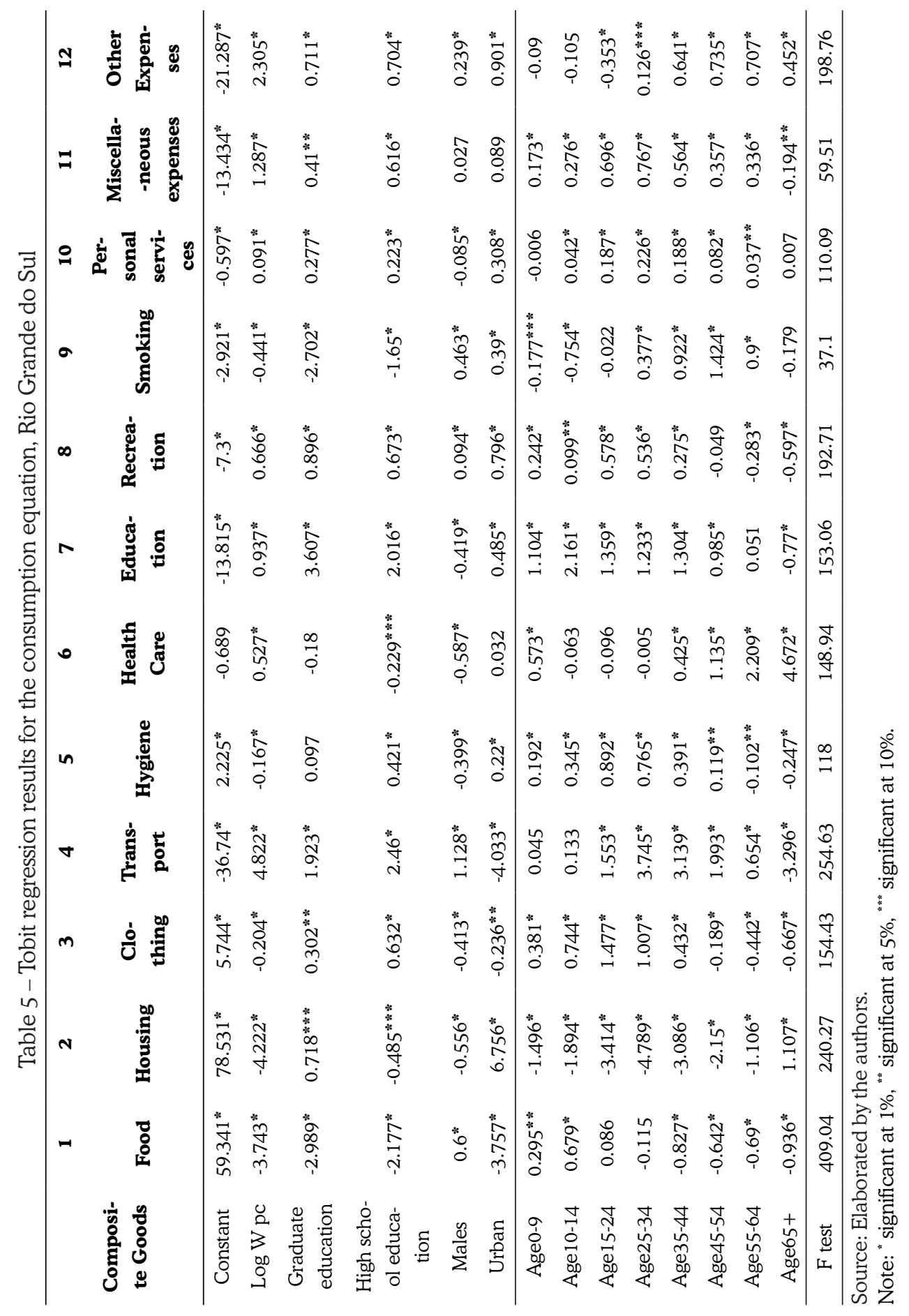


Except for food, housing, clothing and smoking, the logarithm of per capita income has a positive effect on consumption in Brazil and in RS (including also hygiene in the exceptions). Per capita income seems to have a greater positive impact on transport and a greater negative impact for housing, even for Brazil or RS, so that a $1 \%$ increase in per capita income pushes up consumption by 3.4713 for transport and pushes down consumption by -4.9135 for housing for Brazil. ${ }^{6}$ On the other hand, for hygiene in Brazil, the effect of income is practically null, indicating that income probably does not affect the demand for this composite good. For RS, hygiene has a negative impact in terms of per capita income. This difference could be associated to the characteristics of the composite good since hygiene can be an inferior good and to the fact that per capita income is higher in RS than in Brazil.

Considering the impact of instruction skills (graduate and high school education) on consumption, it is found that the higher the education level the less is the consumption both in Brazil and RS for housing, health care, education, recreation, personal services and other expenses, which results are consistent with the literature. On the other hand, food, clothing, transport, hygiene, smoking and miscellaneous expenses are composite goods which demand increase with education. This effect may be explained by the preferences of the more educated people, searching for quality or sophistication and thus consuming more expensive goods. For example, with a higher level of education, people can choose natural food, as it is healthier, but it is also more expensive. Despite they still buy clothes, they can prefer a fashionista brand which it is also more expensive. The result for smoking is also interesting, and may be explained because cigarettes emerged with the north American film industry, and it was a popular good. Although it`s a good that harms the health, it`s still a popular good (ROSIÈRE; ROSIÈRE JÚNIOR, 2012).

If the person is male, it is also an important variable when analyzing consumption in different sectors. The results indicate that being male has a positive effect on consumption for the following composite goods: food, transport, recreation, smoking, miscellaneous expenses and other expenses. Other composite goods have a negative influence associate with being male (or positive in the case of female): housing, clothing, hygiene, health care, education, and personal services. These results make sense as, usually, men eat more than women and women concern more about clothes than men.

The effect of age on consumption is the critical point in this study. If retirement consumption puzzle matters for Brazil and Rio Grande do Sul, it would be expected a large drop in consumption of composite goods as people get older. To achieve a better comprehension about this issue from the estimation results, we plot the marginal effect on expenditure related to the age groups in four graphs

$6 \quad$ Note that in the methodology section it was shown that the impact of the marginal effect of the explanatory variables is the coefficient multiplied by a correction factor, which was done here. 
separating the composite goods for which expenditures decreases (Graphs 1 and 2), increases (Graph 3) and keep constant or increases and decreases at advanced ages (Graph 4).

The results indicate that expenditure decreases for food, clothing, hygiene, education, recreation and miscellaneous expenses for Brazil and RS (Graph 1). These results are quite similar to that found by Lefèbvre (2006) in a study for Belgium where the same effect was observed for composite goods such as food, clothing, transport, education and hygiene. However, differently from that study, we found a drop in consumption for recreation, which may be explained by the fact that some recreational goods (theatre, musical concerts, etc.) can be expensive considering the average income at retirement, but also because Brazil have not developed public policies orientated for the old people. In Brazil, only in 1994 it was instituted a national policy for elderly people, despite initiatives of the Federal Government in the 70s in favor of this age group (FERNANDES; SOARES, 2012).

Educational expenditures usually are more relevant for people when they are young (childhood and adolescence). In fact, the age-earnings profile shows that people have a cost of education at the short run but will be benefited in the long run with higher returns (MINCER, 1974). Additionally, the results reveal that expenditures on education have the most expressive drop for age from 55 years old which is not surprisingly considering that the retirement rate for those ages is very high in Brazil.

Graph 2 show that transport expenditures have the highest peak at young ages (25-34 years) and strongly decline after age 64. It is also interesting to note from Graph 1 that expenditure peaks at the ages 10-14 years for food and education and at the ages 15-24 years for clothing. These peaks are reasonable since the human body is developing during childhood and adolescence, implying the need for more food and substitution of clothes. Also, accordingly to data from INEP for 2012, in Brazil the amount of young people enrolled in basic education (50,5 millions) overcomes the amount that enrolled in graduate education (7,0 millions). Another composite goods having the highest peak at the ages 15-24 years are hygiene and recreation. 
Graph 1 - Expenditures that decreases with age (excluding transport good)

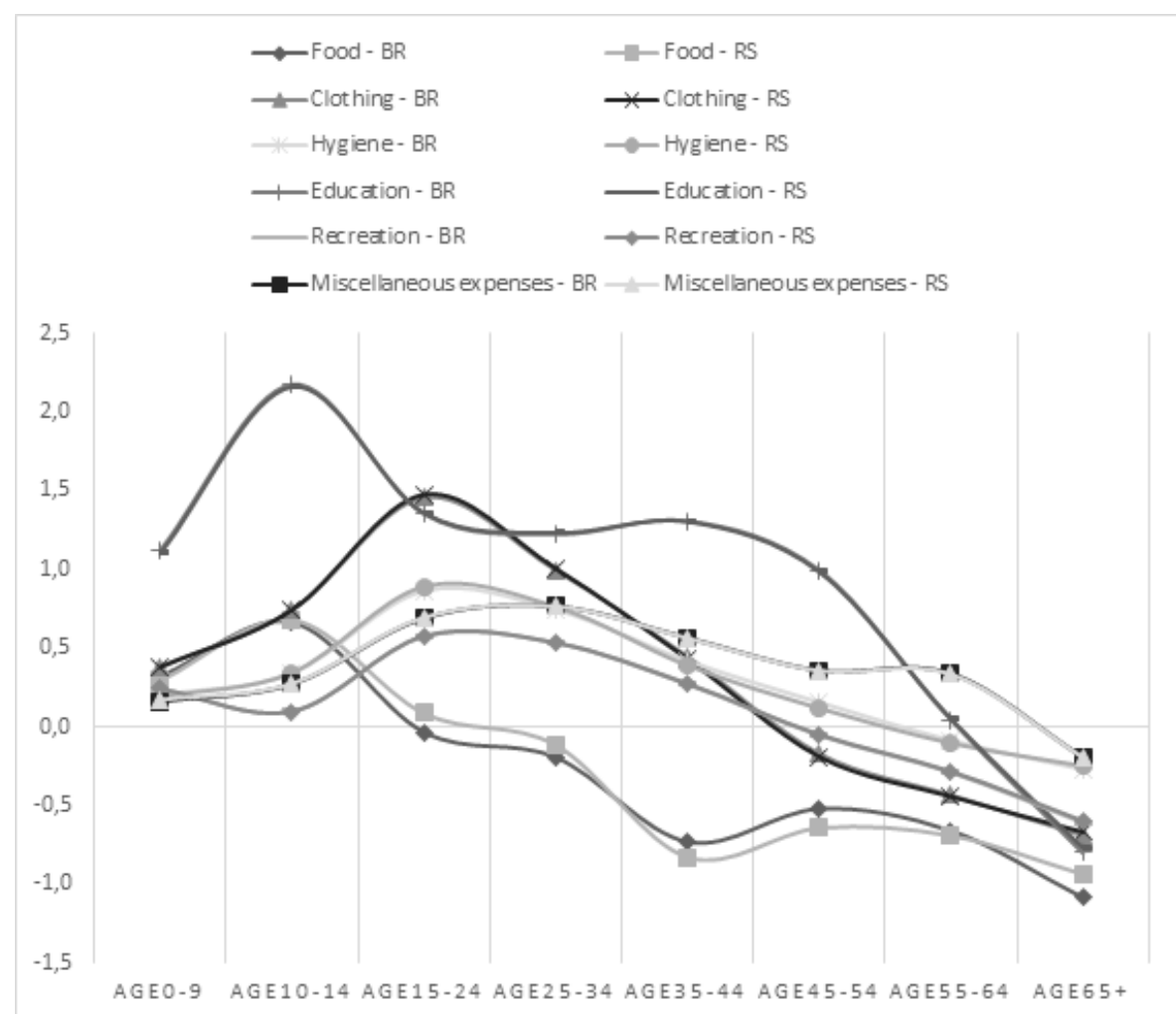

Source: Elaborated by the authors. 
Graph 2 - Expenditures that decreases with age (only transport good)

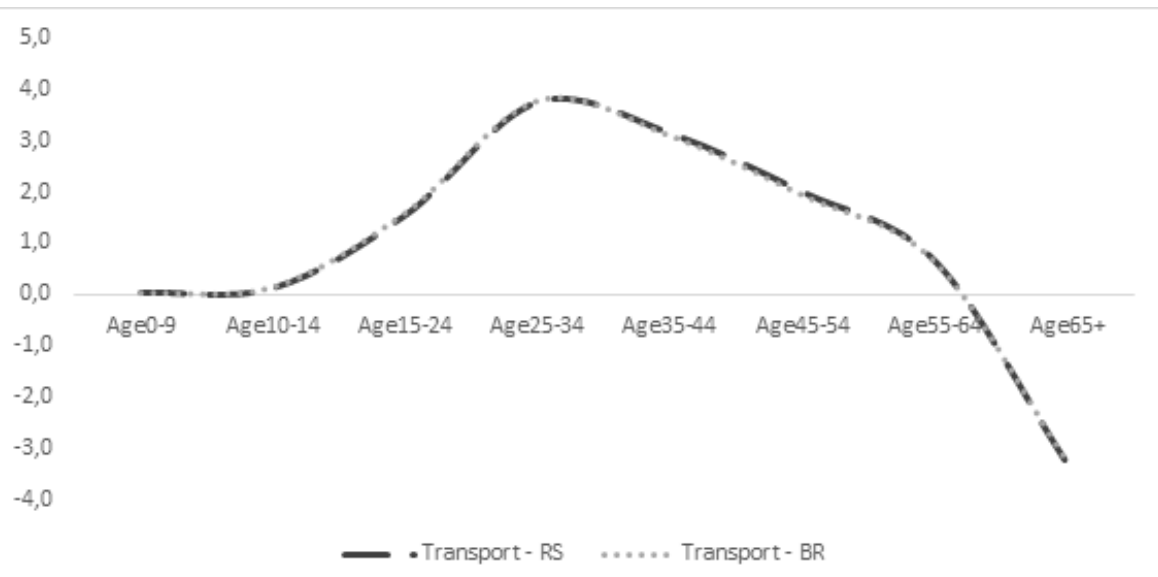

Source: Elaborated by the authors.

As expected, expenditures with health care and housing increase with age (Graph 3) both in Brazil and Rio Grande do Sul. This result was also found in the study of Lefébvre (2006). It is worth noting that those expenditures increase exponentially from the ages at 25-34 years. For health expenditures, such an increase probably is related to the high cost of provision of private health goods and services and because elderly have more health problems and demand more these goods and services. Also public health consumption significantly increases with age. Turra (2001) shows that the government expenditure per age growths exponentially over 49 years old and for people over 60 years old the average per capita expenditure of the government is twice bigger than the age group between 30-39 years. In spite of the observed negative effect of age for housing goods, usually demand increases at more advanced ages since families need to accumulate money during the initial period of life cycle to buy houses.

Graph 4 shows that personal services expenditure remains during life cycle but smoking expenditures strongly increase from age at 10-14 years until age at 45-54 year and then quickly fall. Smoke is known as a habit hard to change over the life cycle with several consequences on health conditions. The prevalence of nicotine addiction in Brazil is similar to the United States, representing about $24 \%$ (GALDURÓZ et al., 1999). This indicator didn `t change very much since 1965 in United States (FIORE; BAILEY; COHEN, 1996), so it can be considered as a good with persistent consumption over time.

Summing up, the pattern of the household expenditures over the life cycle coming from this empirical analysis allow us to conclude for the evidence of retirement consumption puzzle in Brazil, mainly considering the age effects achieved 
for relevant composite goods into the household budget such as food, clothing, transport, hygiene, education, recreation and miscellaneous (see Tables 2 and 3). As the results for Rio Grande do Sul are highly correlated to that for Brazil and this state have the most advanced demographic transition process, the evidences obtained in this study raises the importance to evaluate the effect of demographics on consumption and economic performance.

Graph 3 - Expenditures that increases with age

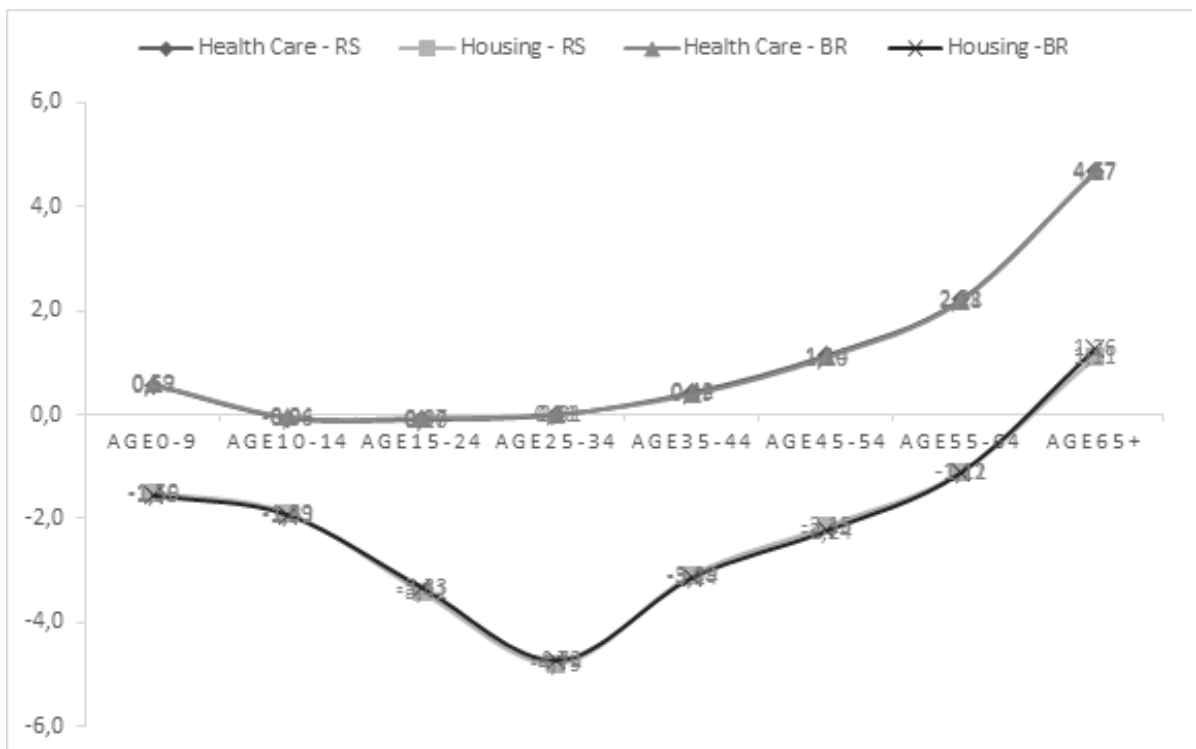

Source: Elaborated by the authors. 
Graph 4 - Expenditures that remain constant or decreases at advanced ages

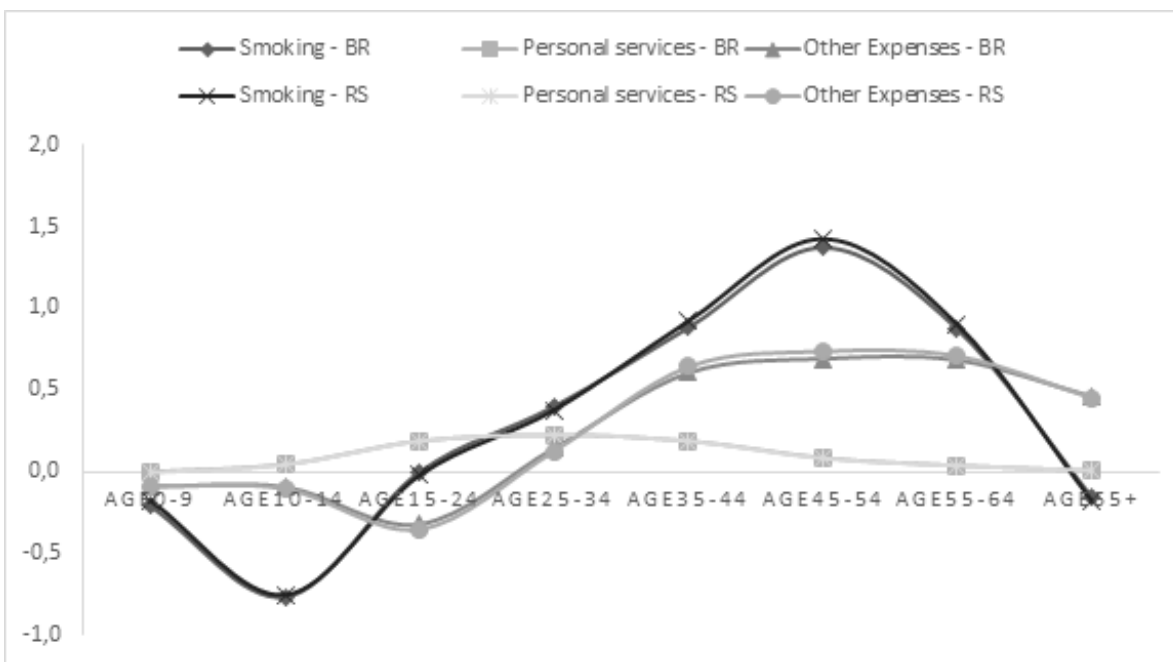

Source: Elaborated by the authors.

\section{Final Considerations}

Demographics is a factor that has a major impact on consumption. The traditional Keynesian Theory introduced the concept marginal propensity to consume and postulated that current income explains consumption. Other approaches, such as the life cycle/permanent income theories postulates that rational behavior of households imply that consumption is constant over time.

In this paper we search for evidences on the so-called "retirement-consumption puzzle" which represents a significant drop in consumption at retirement found in some empirical studies. If such effect exists consumption would be not constant over time, putting into question the main hypothesis and results of the LCPIT. It is worth noting that the rational expectation hypothesis raised by Hall (1978) and used into the framework of the LCPIT imply the information set possessed by households at the current time is not correlated with the household's expectation error (HAIDER; STEPHENS JR., 2007). A possible violation of this assumption would be related to "unanticipated shocks occurring around the time of retirement" (BANKS, BLUNDELL; TANNER, 1998), which affect the household's foresight capability and the saving's schedule of households would be set no properly to support consumption at retirement.

Our study addressed this issue for Brazil and the State of Rio Grande do Sul. We estimate consumption functions controlling for age effects for 12 composite goods defined from the 2008-2009 Household Budget Survey following the strate- 
gy adopted by Lefèbvre (2006) and Farinha (2008). The results showed that households' expenditures consistently decrease with age for 7 composite goods (food, clothing, transport, hygiene, education, recreation and miscellaneous) and increase with age for 2 composite good (health care and housing). It was also found that other composite goods such as smoking and personal services tend to increase until the age group at 45-54 years old but still decrease at retirement ages.

These results put in evidence the retirement consumption puzzle for Brazil and Rio Grande do Sul. This evidence about such puzzle into the international studies is still ambiguous (BATTISTIN et al., 2009; LI; CHI; WU, 2015), being an important issue to be explored using other econometric tools. However, as demographic transition evolves very quickly in Brazil as well as in Rio Grande do Sul, the evidences achieved in this study bring concerns about the economic growth effects from the channel coming from consumption and demographics. To our view, studies about the relationship among demographics, consumption and economic growth are very important to the context of the demographic transition in Brazil and need to be more explored into the economic research agenda.

\section{References}

ALVES, J. E. D. A transição demográfica e a janela de oportunidade. São Paulo: Instituto Fernand Braudel de Economia Mundial, 2008.

. O bônus demográfico e o crescimento econômico no Brasil. In: Aparte: inclusão social em debate. Rio de Janeiro: Instituto de Economia, Universidade Federal do Rio de Janeiro, 2004.

AZARIADIS, C. The theory of poverty traps: what have we learned? In: BOWLES, S.; DURLAUF, S.; HOFF, K. (Ed.). Poverty Traps. Princeton, NJ: Princeton University Press, 2006.

AZZONI, C. R.; MENEZES-FILHO, N. A.; MENEZES, T. A. Opening the convergence black box: measurement problems and demographic aspects. In: KANBUR, R.; VENABLES, A. (Ed.). Spatial inequality and development. Oxford: Oxford University Press, 2005

BANKS, J.; BLUNDELL, R.; TANNER, S. Is there a retirement-savings puzzle? American Economic Review, v. 88, n. 4, p. 769-788, Sept. 1998.

BATTISTI, I. D. E. Análise de dados epidemiológicos incorporando planos amostrais complexos. 2008. 198 f. Tese (Doutorado em Epidemiologia) - Faculdade de Medicina, Universidade Federal do Rio Grande do Sul, Porto Alegre, 2008.

BATTISTIN, J. et al. The retirement consumption puzzle: evidence from a regression discontinuity approach. American Economic Review, v. 99, n. 5, p. 2209-2226, Dec. 2009.

BERNHEIM, B.; SKINNER, J.; WEINBERG, S. What accounts for the variation in retirement wealth among U.S. households? American Economic Review, v. 91, n. 4, p. 832-857, Sept. 2001. 
CAMERON, A.; TRIVEDI, P. Microeconometrics using Stata, StataCorp LP. Texas: College Station, 2009.

DORNBUSCH, R.; FISCHER, S. Macroeconomia. Rio de Janeiro: McGraw-Hill, 1982.

FAIR, R.; DOMINGUEZ, K. Effects of the changing U.S. age distribution on macroeconomic equations. American Economic Review, v. 81, n. 5, p. 1276-1294, Dec. 1991.

FARINHA, L. Os efeitos da riqueza sobre o consumo em Portugal: uma abordagem microeconométrica. Lisboa: Departamento de Estudos Econômicos, Banco de Portugal, 2008. (Relatório de Estabilidade Financeira).

FERNANDES, M. T. O.; SOARES, S. M. O desenvolvimento de políticas públicas de atenção ao idoso no Brasil. Revista da Escola de Enfermagem da USP, São Paulo, v. 46, n. 6, p. 14941502, 2012.

FIORE, M. C.; BAILEY W. C.; COHEN, S. J. Smoking cessation: Clinical Practice Guideline, 18. Rockville, DUS Department of Health and Human Services, Public Health Service, Agency for Health Care Policy and Research, 1996.

GALDURÓZ, J. C. F. et al. Primeiro levantamento domiciliar nacional sobre o uso de drogas psicotrópicas. Parte A: estudo envolvendo as 24 maiores cidades do Estado de São Paulo. São Paulo: Unifesp/Cebrid, 1999.

HAIDER, S. J.; STEPHENS JR., M. Is there a retirement-consumption puzzle? evidence using subjective retirement expectations. The Review of Economics and Statistics, v. 89, n. 2, p. 247264, May 2007.

HALL, R. E. Stochastic implications of the life cycle-permanent income hypothesis: theory and evidence. Journal of Political Economy, v. 86, n. 6, p. 971-987, Dec. 1978.

HAMERMESH, D. Consumption during retirement: the missing link in the life cycle. Review of Economics and Statistics, Cambridge, v. 66, n. 1, p.1-7, Feb. 1984.

HURD, M.; ROHWEDDER, S. The retirement-consumption puzzle: anticipated and actual declines in spending at retirement. Cambridge, MA: National Bureau of Economic Research, 2003.

IBGE. Censo 2000: questionários. Rio de Janeiro: IBGE, 2000. Disponível em: < http://www. ibge.gov.br/censo/questionários.shtm>. Acesso em: 25 ago. 2013.

. Pesquisa de orçamentos familiares 2002-2003: primeiros resultados - Brasil e Grandes Regiões. Rio de Janeiro: Ministério do Planejamento, Orçamento e Gestão; IBGE, Diretoria de Pesquisas, Coordenação de Índices de Preços, 2004b.

Pesquisa de orçamentos familiares 2008-2009. Microdados. Rio de janeiro, 2010. Disponível em: <http://www.ibge.gov.br/home/estatistica/populacao/condicaodevida/ pof/2008_2009/microdados.shtm>. Acesso em: 20 nov. 2016.

KEYNES, J. M. A teoria geral do emprego, do juro e da moeda. São Paulo: Atlas, 1982.

LEFÈBVRE, M. Population ageing and consumption demand in Belgium. Liège: CREPP, 2006. 
LI, H.; SHI, X.; WU, B. The retirement consumption puzzle in China. American Economic Review, v. 105, n. 5, p. 437-441, May 2009.

MENEZES, T. A.; SILVEIRA-NETO, R.; AZZONI, C. R. Demography and evolution of regional inequality. The Annals of Regional Science, v. 49, n. 3, 2011.

MILES, D. Modelling the impact of demographic change upon the economy. The Economic Journal, v. 109, n. 452, p. 1-36, Jan. 1999.

MINCER, J. Schooling, Experience and Earnings. New York: Columbia University Press, 1974.

MODIGLIANI, F. The life-cycle hypothesis and intercountry differences in the saving ratio. In: ELTIS, W. A.; SCOTT, M. F.; WOLFE J. N. (Ed.). Induction, growth, and trade: essays in honour of Sir Roy Harrod. Oxford: Oxford University Press, 1970.

MORAES, M. A. S.; FAMÁ, R.; KAYO, E. K. Teorias de consumo/poupança e o sistema previdenciário Brasileiro. Cadernos de Pesquisa em Administração, São Paulo, v. 1, n. 6, p. 44-52, 1998.

ROSIÈRE, B. C.; ROSIÈRE JÚNIOR, A. C. A. Indústrias de tabaco e responsabilidade civil. Florianópolis: Fundacao Boiteux, 2012.

SCHWERDT, G. Why does consumption fall at retirement? Evidence from Germany. Economics Letters, v.89, n. 3, p. 300-305, 2005.

SILVA, P. L. N.; PESSOA, D. G. C.; LILA, M. F. Análise estatística de dados da PNAD: incorporando a estrutura do plano amostral. Ciência e Saúde Coletiva, v. 7, n. 4, p. 659-70, 2002 .

SMITH, S. Can the retirement-consumption puzzle be resolved? Evidence from U.K. panel data. London: Institute of Fiscal Studies, 2004. (Working paper, n. 04/07).

STATA. Data analysis and statistical software. 2013. Available in: < http://www.stata.com/ manuals13/svysvyestimation.pdf >. Access in: 12 Aug. 2013.

TURRA, C. M. Intergenerational accounting and economic consequences of aging in Brazil. In: INTERNATIONAL UNION FOR THE SCIENTIFIC STUDY OF POPULATION GENERAL CONFERENCE, 24., 2001, Salvador. Proceedings... Salvador: IUSSP, 2001.

VIEIRA, M. T. Um estudo comparativo das metodologias de modelagem de dados amostrais complexos: uma aplicação do SAEB 99. 2001. 108 f. Dissertação (Mestrado em Ciência da Engenharia Elétrica) - Pontifícia Universidade Católica do Rio de Janeiro, Rio de Janeiro, 2001.

WONG, L. R.; CARVALHO, J. A. O rápido processo de envelhecimento populacional do Brasil: sérios desafios para as políticas públicas. Revista Brasileira de Estudos Populacionais. São Paulo, v. 23, n. 1, p. 5-26, jan./jun. 2006.

WOOLDRIDGE, J. M. Introductory econometrics: a modern approach. 2. ed. New York: Thomson Learning, 2008.

Recebido em: 21/04/2014. Aceito em: 22/11/2016. 